\title{
Türkçede Metaforlar ve Metaforik Anlatımlar
}

\section{Metaphors and Metaphorical Expressions in Turkish}

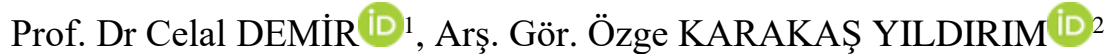

\begin{abstract}
Özet
"Metafor" kavramı, Batı literatüründe eski Yunan filozofu Aristoteles’ten bu yana hem terim hem de leksik bir unsur olarak bilimsel çalışmalara konu olmuş, her yönüyle tartışılmış ve uygulamada fikir birliğine varılmıştır. Bu kavramın gerek sanat alanında gerekse bilim dallarındaki pratikleri, eğitim-öğretim kurumlarında bir ders olarak okutulmakta ve öğretilmektedir. Türkiye Türkçesi literatüründe "metafor", "metaforik anlatım" ve "metaforik adlandırma" ile ilgili tartışmalar yeni başlamıştır. Çeşitli metaforların kavram ve tasavvur olarak Türk kültüründe de bin yıl öncesinden oluştuğu, bu tasavvurların anlama ve anlatma unsuru olarak günlük yaşamda kullanıldığı bilinmektedir. Bunun örneklerine yaklaşık bin üç yüz yıl önce yazılmış olan Göktürk metinlerinde de rastlamaktayız. Ancak bu konuda yapılmış çalışmaların sayıca az olduğunu, bazı kaynaklarda verilen bilgilerin de yetersiz olduğunu görmekteyiz. Bazı çalışmalarda "metafor" olgusunun terim ve kavram olarak tartışılmadı̆̆ı, bazı çalışmalarda yer alan bilgi ve açıklamaların yanlış veya yetersiz olduğu görülmüştür. Güncel sözlüklerde ve ansiklopedilerde ise gerektiği gibi açıklanmamıştır. Hatta bazı sözlüklerde bu kelimeye madde başı olarak hiç yer verilmemiştir. $\mathrm{Bu}$ çalışmanın amacı, literatürümüze yeni girmiş olan "metafor" terimiyle ilgili tespit, tanım ve açıklamaları inceleyip eksik ve yanlışları belirleyerek düzeltilmesini sağlamaktır. Bu nedenle "metafor" kelimesinin terim olarak tanımı, kavram olarak özellikleri üzerinde durulmuş ve "metafor" olgusunun "mecaz" terimiyle açıklanamayacağı vurgulanmıştır. Ayrıca metaforik anlatım ve adlandırmaların Türk kültüründe yeni bir tarz olmadığı, dilimizin bilinen en eski metinlerinde bile metaforik anlatımlara ve adlandırmalara yer verildiği örnekler üzerinde gösterilmiştir.
\end{abstract}

Anahtar kelimeler: metafor, mecaz, metaforik anlatım, metaforik adlandırma

Makale Türü: Derleme

\begin{abstract}
In this study, the definition of the "metaphor" as a term and its features as a concept is emphasized, it is also emphasized that the phenomenon of "metaphor" cannot be explained with the figurative meaning and the terms of "metaphorical expression" and "metaphorical naming" are discussed on the examples. The concept of "metaphor" has been the subject of scientific studies, both as a term and a lexical element, discussed in all aspects and has become stable in the practice since the ancient Greek philosopher Aristotle in the Western literature. Practices both in the field of art and science are taught in educational institutions. The discussions about "metaphor", "metaphorical expression" and "metaphorical naming" in Turkish have recently begun. It is known that various metaphors in Turkish culture as a concept and thought were formed a thousand years ago, and these thoughts were used in daily life as an element of understanding and expression. Examples of this can be found in the Gokturk texts written a thousand and three hundred years ago. However, we see that there are few studies on this subject and the information given in some sources is insufficient. It was seen that in some studies "metaphor" was not discussed as terms and concepts. The information and the explanations in some studies were insufficient as well. In the current dictionaries and encyclopedias, metaphor is not properly explained. Some dictionaries do not even include this word at all.
\end{abstract}

Keywords: metaphor, figurative meaning, metaphorical expression, metaphorical naming

Paper Type: Review

${ }^{1}$ Prof. Dr., Afyon Kocatepe Üniversitesi, Eğitim Fakültesi, cdemir@aku.edu.tr.

${ }^{2}$ Ar. Gör., Afyon Kocatepe Üniversitesi, Eğitim Fakültesi, ozgekarakas@ windowslive.com.

Atıf için (to cite): Demir, C ve Karakaş Yıldırım, Ö. (2019) Türkçede Metaforlar ve Metaforik Anlatımlar. Afyon Kocatepe Üniversitesi Sosyal Bilimler Dergisi, 21(4), 1085-1096. 


\section{Giriş}

Batı dillerinde uzun bir geçmişi olan "metafor" terimi, Türkiye Türkçesine geçtiğimiz yüzyılın sonlarında girmiş ve farklı alanlarda kullanılmaya başlamıştır. Ancak her yönüyle keşfedildiğini ve anlama- anlatma çalışmalarında etkin ve doğru kullanıldığını söyleyemeyiz.

Gerek terim sözlüklerinde gerekse güncel sözlüklerde anlam çerçevesi tam olarak tespit edilemediği ve donmuş bir unsur olarak tanımlanmadığı için kullanımında ve öğretiminde sorunlar yaşanmaktadır. Her ne kadar bu kavramla ilgili incelemeler yapılmış, açıklayıcı yazılar kaleme alınmış olsa da bu çalışmalarda, çoğu kez, "mecaz" ile "metafor" birbiriyle özdeş iki terim olarak gösterilmiş ve "metafor" ile "metaforik anlatım" birbirinden ayrılmamıştır.

Batı dillerinde (İngilizce, Fransızca, Almanca, İspanyolca) "metafor" hem farklı bilim dallarında özel anlamları karşılayan bir terim olarak hem de ortak dilde yaşayan bir kavram olarak değerlendirilmektedir. Hatta modern çağdan önceki hâlleri ve mevcut kullanımları birbirinden ayrılarak ele alınmakta ve incelenmektedir. Özellikle Lakoff ve Johnson'un çağdaş metafor teorisi (Metaphors We Live By, 1980), pek çok bilimsel disiplini etkilemiş, farklı yaklaşım ve tasniflerin başlama ve çıkış noktası olmuştur. "Doğal olarak, çok çeşitli görüşler ortaya çıkmış ve temel olarak bunlar sırf retorik ve biliş doğrultusunda metaforu yorumlayan geleneksel metafor ve modern metafor olmak üzere iki okula ayrılmıştır” (Zhang, 2009).

Her ne kadar bu kavram Türkiye'de yazınbilim/retorik başta olmak üzere, lengüistik, felsefe, sosyoloji ve pedagoji gibi alanlarda yaygın olarak kullanılmakta ise de gerektiği gibi ve yeterli düzeyde incelenmediğini, üretilen bilgi ve materyalin öğreti kitaplarına konabilecek stabil bilgi hâline henüz gelmediğini belirtmek durumundayız. Literatürdeki tercümelerin de henüz özümsenmediğini söylemek yanlış olmaz. Mevcut yayınlarda "metafor" teriminin yardımı ile açıklanması gereken kavramların "mecaz”, "düz mecaz", "ad aktarması”, “deyim aktarması”, "değişmece", "istiare", "telmih" gibi terimlerle karşılandığını, zaman zaman da bu terimlerin yetersiz kaldığı yerlerde ilave/destekleyici açıklamalar yapıldığını görmekteyiz. Bu durum, sözlü ve yazılı ifade geleneğimizde öteden beri var olan ama adı konmamış bir anlatım tarzının varlı̆̆ını belgelemekte ve onu karşılayacak bir terime ihtiyacımız olduğunu göstermektedir.

\section{Terim Olarak Metafor}

Metafor, esas olarak, eski Yunan filozofu Aristoteles’ten günümüze retorik, lengüistik, felsefe, semiyotik, psikoloji, pedagoji gibi farklı alanlarda kullanılagelmiş bir anlatı ve pedagoji terimidir. "Metafor", günümüzde daha çok bir retorik (edebiyat, anlatı sanatı, belagat) terimi olarak biliniyor olsa da psikoloji, sosyoloji, dilbilim ve pedagoji gibi bilim dallarında da anlatım ve öğretim aracı olarak kullanılmaktadır.

Metafor (Fr. métaphore, İng. metaphor) kelimesi, Eski Yunancada bir kavram1, bir olguyu, kendinden daha öteye taşımak, olduğundan daha fazlasını yüklenmek anlamındaki Yunanca "phérō" sözcüğünden gelmektedir (Dur, 2016: 123). Kelimenin etimolojisini yapanlara göre de "Metafor kelimesi, meta: öte ve pherein: taşımak, yüklenmek kelimelerinden mürekkeptir" (Lakoff ve Johnson, 2015: 15). Bu yaklaşıma göre kelimenin morfolojisine bakıldığında "phérō" kelimesine "meta" ön eki getirilerek türetilmiş olduğu anlaşılmaktadır.

Fransızca sözlüklerde, (Dictionnaire Hachette Collége, 2008 ) ise " métaphore: (nom féminin) Procéd qui consiste à utiliser un mot dans un sens figuré. Quand on parle du "printemps de la vie" pour désigner la jeunesse, un emploie une métaphore" 3 şeklinde açıklanmakta ancak "mecaz" kelimesi yerine "metaforik anlatım" terimi tercih edilmektedir.

Güncel Türkçe sözlüklerde ve terim sözlüklerinde bir sanat terimi olarak da ele alınıp tanımlanmaktadır. "Metafor" ve "metaforik" terimlerinin ifade ettiği tüm kategoriler;

\footnotetext{
${ }^{3}$ Bir kelimeyi başka bir anlamı düşündürecek şekilde kullanmak. "Hayatının baharında ..." dendiği zaman metaforik bir anlatım yapılmış olur.
} 
"iğretileme", "istiare", "mecaz", "kinaye", "telmih" gibi mecaz ve mecazın türevleriyle açıklanmakta ve sinırlandırılmaktadır. Örneğin Türkçe Sözlük'te (TDK, 2015) "metafor" sözcüğü, "mecaz" kelimesiyle karşılanmakta, "metaforik" ise, "metafora ait, metaforla ilgili"" biçiminde açılanmaktadır. Büyük Türkçe Sözlük'te (Doğan, 1999),"metafor" kelimesi; "mecaz", "istiare", "kinaye" ve "teşbih" kelimeleriyle açıklanmaktadır. Misalli Büyük Türkçe Sözlük'te (Ayverdi, 2016) de, aynı şekilde "istiare" ve "ödünçleme" terimleriyle eş anlamlı gösterilmektedir. Terim sözlüklerinde ise aynı açıklamalara küçük ilaveler yapılarak metaforun bir sanat terimi olduğuna vurgu yapılmaktadır (Karaağaç, 2018 ). Fransızca -Türkçe Sözlükte de métaphore: "eğretileme", "istiare" şeklinde açıklanmaktadır (Saraç, 1999).

Türkçeye Arapçadan gelmiş olan "istiare" sözcüğü, "ödünç/borç verme/alma” anlamına gelen "are" kökünden türetilmiştir. Türkçe sözlüklerde de bu terim açıklanırken kelime kökündeki temel anlam esas alınmaktadır.

Edebiyat incelemelerinde ise "metafor", söz sanat1/retorik terimi olarak kullanılmakta ve metindeki anlatım biçimi, kullanıma göre "mecaz-ı mürsel","teşbih-i beliğ", "açık istiare" / “düz mecaz" gibi söz sanatları ile açıklanmaktadır (Filizok, 2005).

Osmanlı Türkçesi sözlüklerinde ise, "metafor" ve "metaforik anlatım”a tekabül eden anlamlar, "mecaz" kelimesiyle açıklanmaktadır (Devellioğlu 2010, Parlatır 2017). Biraz daha eski kaynaklarda ve ansiklopedilerde ise bu anlamların "lâfız-mana", "i'câz/vecîz", "telmih" gibi kelimelerle ilişkilendirildiğini görüyoruz (Ahterî-i Kebir 2009, Lügat-i Nâcî 2009).

Sonuç itibariyle hem "eğretileme" hem de "istiare" sözcüğ̈̈, Türkçede bir anlatım terimi olarak kullanılmaktır. Ancak bu kelimelerin "metafor" sözcüğü ile eş anlamlı gösterilmesi hemen düzeltilmesi gereken ciddi bir yanlışliktır.

\section{Kavram Olarak Metafor}

"Metafor" bir kelime olarak İngilizce sözlüklerde birbirine yakın fakat farklı amaçlara yönelik iki anlamı karşılamaktadır. Türkiye Türkçesinde "söz figürü" veya "sembol" kelimeleriyle karşılayabileceğimiz bu anlamların, birincisi "bir belirleyici kelime ya da kelime grubunun farklı ama kendisine benzeyen bir nesneye ya da eyleme transfer edilmesi ile oluşan hakiki anlamda da kullanılabilen söz figürü; ikincisi ise kavramsal sunum olarak görülen bir şeyin sembol olarak belirtilmesi" (Gasset, 1948; Akt: Danışman, 2015: 48) biçiminde açıklanmaktadır.

Lakoff ve Johnson'ın çalışmalarında metaforların önce zihinde oluştuğuna vurgu yapılmaktadır. "Gündelik kavram sistemimiz- kendileriyle düşündüğümüz ve eylemde bulunduğumuz terimler- temelde doğası gereği metaforiktir" (Lakoff ve Johnson, 2015: 27). Çağdaş metafor incelemelerinde metafor, sadece bir söz figürü olarak değil, aynı zamanda bir düşünce figürü olarak da değerlendirilmektedir (Akşehirli, 2005).

Esas itibarıyla "metafor" teriminin tüm anlamları, Batı dillerinde "götürmek, göndermek" eylemleriyle ilişkilendirilmiştir. Zamanla bu temel anlam üzerinde ve etrafinda bir kavram ailesi oluşmuştur. Bu kavramlar "ötelere gönderme, yönlendirme, anıştırma, başka bir şeyle buluşturma, benzeşme, ilişkilendirme" biçiminde çoğaltılarak bu terim için metin incelemelerinde ve pedagojide geniş bir manevra alanı yaratılmıştır. Türkçede ise bir sanat (edebiyat, belagat, retorik) terimi olarak ele alınmakta fakat sözlüklerin çoğunda ayrıntılar ve farklılıklar belirtilmeden "mecaz" kelimesi ile eş anlamlı gösterildiği için sözlü ve yazılı kültürde bir kavram olarak teşekkül etmiş tüm metaforlar, bu terimin içinde yahut gölgesinde yok olmaktadır. Ayrıntılı incelemelerde ve daha dikkatli yapılmış çalışmalarda ise "metaforik anlatım" yerine çoğu kez "mecaz ailesi"ne ait diğer terimler tercih edilmekte, bu terimin yetersiz kaldığı veya kavramla örtüşmediği durumlarda ilave açıklamalara başvurulmaktadır.

\section{Metafor ile Mecaz Aynı Şey mi?}

Yazıl1/sözlü edebiyattaki kullanımlar ve günlük hayattaki pratikler dikkate alındığında "mecaz" ile "metafor"un bir terim olarak aynı durumları ifade etmediği açıkça görülmektedir. 
Her ikisi de sanat (retorik/belagat) terimi olmakla birlikte karşılamış oldukları kavramlar hem görünürde hem de derin yapıda birbirinden farklı özellikler göstermektedir. "Mecaz", bir anlam inceliği yaratmak, sözün etkisini artırmak veya anlamayı/anlatmayı kolaylaştırmak amacıyla bir durumu, bir olguyu, bir kavramı veya bir eylemi kendi adıyla söylemek yerine bu durumlarla iliş̧kisi olan başka bir kelimeyi kullanarak anlatmak; bir kelimeyi geçici olarak başka bir kelimenin yerine kullanmak (ödünçleme yapmak) biçiminde açılanabilir (Karataş, 2018). Neticede mecaz, bir şeyi kendi adı veya özelliği ile ifade etmek yerine "bir anlam inceliği yaratmak / dikkat çekmek için" kasıtlı olarak o şeyi, başka bir şeyin adı veya özelliği ile anlatmaktır. Bu bağlamda mecaz, farklı bir anlatma biçimi, doğrudan anlatım dışında başvurulan farklı bir anlatım yolu olarak önümüze gelmektedir. "Metafor" ise Türkçeye uyarlandığında bir anlatım biçimi veya tarz değil, böyle bir anlatım tarzının içinde anlatım aracı olarak kullanılan müstakil bir unsura tekabül etmektedir. Mecaz iki kelime arasındaki alış-verişi / gidiş-gelişi yani ödünçlemeyi ifade etmektedir. Metafor ise donmuş (gelişmesini tamamlamış / stabil) veya gelişmekte / oluşmakta olan, kurgulanmış veya kurgulanmakta olan bir tasavvurun kendisidir. Bu tasavvur donmuş bir hikâye, bir aforizma, bir eşya, bir kavram, meşhur bir olay, bir eylem, bir fikra, önemli özelliği olan bir insan veya başka bir varlık da olabilir. Şu hâlde anlatı sanatında metafor, bir eylem biçimi, bir ifade manevrası değil, bu eylemi kuran ve gerçekleştiren sanatçının kullandığı malzemelerden/unsurlardan biri olarak karşımıza çıkmaktadır.

Mecaz, bir anlatım biçimi; metafor ise bu anlatımda kullanılan anlatım malzemesidir. Metafor, sanatçıya göre anlatımı güzelleştiren veya etkili kılan unsur; muhatabına göre ise okuma hazzı veren yahut anlamayı kolaylaştıran benzerlikten, anıştırma unsurundan ibarettir ki bu durum, okuyucu açısından çoğu kez bir "misal/örnek" işlevi görmektedir.

Özet olarak şöyle ifade edilebilir: "Mecaz", "Bir şeye geçici olarak başka bir isim vermek" iken "metafor", verdiğimiz o ismin içindeki kavram, olgu, olay veya varlıktır. Bu noktada mecaz ile metafor asla aynı anlama veya duruma tekabül etmemektedir. Ancak "metaforik yaklaşım" veya "metaforik anlatım" sözü, bir ifade biçimini/tarzını işaret eder ki bu adlandırma mecazla kısmen de olsa örtüşebilir. Bu bağlamda "metafor, -bir şeyi- başka bir şey yoluyla anlamak (anlatmak değil) ve deneyimlemektir" (Lakoff \& Johnson, 1980: 5; Lakoff \& Johnson, 2015: 30'dan aktaran Balc1, 2003: 30).

"Metafor" kelimesi, leksik bir unsur olarak, mecaz terimiyle anlatılan ve anlatılamayan durumları ifade edebilecek geniş ve kapsamlı bir semantik değere sahiptir. Türkçenin fonetiğine hiçbir yönüyle uymamasına rağmen dilimizde kullanma alanı bulmuş ve yaygınlık kazanmıştır. "Metafor", zaman zaman "şey" kelimesiyle düşündürmeye çalıştığımız kavramları, olgu ve tasavvurları ifade etmek için son yıllarda keşfettiğimiz bir terimdir. Bugün "metafor" terimiyle ifade ettiğimiz tasavvurlar zaten ortak kültürde zaten teşekkül etmiş bulunuyordu. Deyimler, atasözleri, anekdotlar, vecizeler, meşhur olaylar, fikralar ilh. hepsi mevcuttu ve tüm bunlar bir adla çağrılmayı bekliyordu. İşte "metafor" terimi bu boşluğu doldurmaktadır. Hiç kuşkusuz, sözlüklerde metaforun karşısına yazılanlar mecazda olduğu gibi başlangıçta kişisel bir düşüncenin ürünüdür ve özgündür. Fakat bu tasavvurlar toplumun düşünme ve anlatma geleneğine uygun düştüğü için zamanla umumiyet kazanmış ve topluma mal olmuştur. Daha da ötesi ilk düşüneni, ilk söyleyeni unutulmuş ve söz anonimleşmiştir. Bu ürünün kullanımı ise, diğer ifade biçimleri ve metnin türüyle ilişkilendirilmesi tamamen şahsidir ve çoğu zaman da özgündür.

George Lakoff ve Mark Johnson, metafor'un toplumsal veya kişisel hafizada oluşturulmuş bir kavram olduğunu ve her zaman benzetme unsuru olmadığına vurgu yapmaktadırlar: "Metafor kelimelerin değil, kavramların niteliğidir. Metaforun fonksiyonu salt sanatsal/estetik kaygıları değil, belirli kavramları daha iyi anlamaktır. Metafor çoğunlukla benzerliğe dayanmaz. Metafor özel bir yeteneği olmayan siradan insanlarca gündelik hayatta büyük bir zihin faaliyeti gerektirmeksizin kullanılır. Metafor linguistik bir süs, gereksiz bir dekor değil, insanî düşüncenin ve akıl yürütmenin ayrilmaz bir unsurudur." (Lakoff ve Johnson, 2015: 12). Çünkü metafor donmuş veya açık bir tasavvur olarak toplumsal hafizada biçimlenip umumiyet kazanabilir. Metaforun daima içinde bulunduğumuz durumla ve anlatmak istediğimiz 
hâl ile çeşitli yönlerden ilişkilendirilmeye müsait bir tasavvur, obje veya somut bir varlık olması beklenir. Bu durum, kişisel beceri ve ilavelerle edebî metinlerde özgün bir ifade biçimi hâline gelebilir.

Aşağıdaki dörtlükte sanatçı, iki metafor kullanmıştır: birincisi omçaların yaprakları arasında belirginlik kazanıp insanın gözünden aşağılara hesapsız akan gözyaşı damlalarını düşündüren üzüm taneleri/salkımlardır. İkincisinde ise, saçı başı dağılmış, başı öne eğik çok sevdiği birinin ardından hıçkıra hıçkıra ağlayan bir kadın tasavvuru (imajı) vardır. İki gözü iki çeşme ağlayan bu kadının gözyaşları, yağmur yüklü bulutların yere aktığı gibi saçlarının ucundan yerlere akmaktadır. Bu tasavvur, bizi bin yıldan daha eskiye götürüp "yuğ törenlerinde" yanaklarını tırnaklarıyla yırtarak kanını gözyaşlarına katıp akıtan "yuğcu" (Ögel, 1991, C.III) kadın tipini (metaforunu) düşündürmektedir.

"Yüce dağların başında

Salkım salkım olan bulut

Başın çözüp yaşun yaşun

Benim için ağlar mısın"4

Hoang (2014), "Dünyaya bakış açımızı çevremizle, kültürle ve bedenimizle olan günlük deneyimlerimiz, şekillendirir" demektedir. Bir toplumun ürettiği metaforlar, bir kültür muhiti içinde bu deneyimlerden/yaşantılardan doğar. Halkın kavram olarak ürettiği bu malzeme düşünce dünyasının bir şubesi olarak kalmayıp çoğu kez ifade aracı olarak kullanılır. Lowery (2013: 12) ise, "Kullandığımız metaforlar ve daha önemlisi, bunları kullanma tarzımız, bir kültür numunesi olarak çevremizden nasıl etkilendiğimizi ve çevremizi nasıl algıladı̆̆ımızı gösterir." der. Şu hâlde metafor, toplumsal algının, inançların ve toplumsal bakış açısının bir ürünü olarak teşekkül eden tasavvurlar veya yaşamın içinde yer almış, yaşanmakta olan olay, durum veya somut bir nesnenin toplum hafızasında büründüğü/kazandığı son şekildir.

Metafor, bir anlatım biçimi değildir; bir olguyu, bir durumu, bir düşünceyi veya bir olay1 anlatırken, anlatılmak istenen durum, olay veya düşünceyle ilişkilendirilen (gönderme yapılan, kendisine benzetilen, hatırlatılan) bir tasavvur, bir olay, durum veya bir varlıktır. Bu bağlamda metafor; anlatılmak istenen değil, anlatımı ve anlamayı etkileyici kılan, anlaşılmasını kolaylaştıran bir unsur olarak karşımıza çıkmaktadır.

\section{Metaforik Anlatım}

Aslında metaforik anlatımları inceleme tarihi, birbirine benzeyen iki veya daha fazla kavram arasındaki ilişkilendirmeleri sistematize eden Antik Yunan filozofu Aristoteles'e kadar dayanmaktadır (Lyddon vd., 2001: 269). Bu dönemden itibaren "metafor" terim olarak retorik başta olmak üzere, felsefe, dilbilimi, anlambilimi, pedagoji, psikoloji, sosyoloji gibi farklı alanlarda kullanılan bir anlatım unsuru olmuştur. Zhang'a göre metafor, sadece retoriğe ait bir anlatım aracı değil, aynı zamanda dünyayı tanıma ve tanıtma aracıdır (Zhang, 2009). Geçtiğimiz yüzyıla kadar Batı' da dilbilimsel bir olgu olarak görülen metafor kavramı, " 20 . yüzyıldan itibaren sadece dile özgü, dolaylı anlatımı amaçlayan geleneksel görüşün aksine birçok alanda çağdaş yaklaşımların konusu olmuştur" (Lyddon vd., 2001).

Son zamanlarda "metafor" terimi ve "metaforik anlatım"la ilgili çalışmalara Türkiye literatüründe de rastlanmaktayız. Ancak bu çalışmaların, daha çok, edebî şahsiyetlerin eserleri üzerinde yapılan üslup çalışmaları ve/veya tenkit yazıları olduğunu görüyoruz. Bu çalışmalar, "bir yazarın eserlerindeki mecazlar veya mecazlı söyleyişler" veya "bir şairin eserlerindeki söz sanatları" gibi metinler üzerinde yapılmış geleneksel yöntemlerin kullanıldığı mahdut incelemelerden oluşmaktadır. Bu çalışmalarda tespit edilen metaforlar, "mecaz", "kapalı istiare", "mürsel mecaz" bazen de "teşbih" ve "telmih" olarak değerlendirilmektedir. Edebî

\footnotetext{
${ }^{4}$ Yunus Emre
} 
eserlerdeki metaforik anlatımlar ise genellikle "ad aktarması", "deyim aktarması", "hayal", "imaj", "imge" terimleriyle karşılanmaktadır (Demir, 2017: 90). Hâlbuki bu tür incelemelerde özellikle ve öncelikle "metafor" kavramı ile "metaforik anlatım" olgusunun birbirinden ayrılması gerekmektedir. "Metafor", bir kavram olarak halkın üretip ortak kültüre kattığ1 tasavvurların ortak ismidir. "Metaforik anlatım" ise ifade içinde açıklayıcı, düşündürücü, hatırlatıcı veya anlamayı kolaylaştırıcı bir öge olması düşüncesiyle metaforları kullanarak kurulan bir anlatım biçimidir. Yani bu terimlerden birincisi, tasavvur ismi; ikincisi eylem ismidir. Metaforik anlatımı, hem donmuş şekillerden hem de hayattaki anlık olguların tasavvurundan güç alan, hatta toplumsal algılarla ilişkilendirilebilen bir ifade biçimi olarak görmek gerekir. Metaforik anlatım “...bir konuyu diğer bir konunun bakış açısından algılamaya ve anlamaya yönelik olarak kompleks bir fenomen ile zihinde daha önce var olan bilgiler arasında bağ kurma sürecidir” (Dur, 2016: 124) denebilir. Ivie'e (2017) göre de metafor “...birçok insana göre şiirsel dil ve hayal gücü için bir araç”tır. Sanatçı/anlatıcı, bu aracı kullanarak kendince bir anlatım biçimi oluşturabilmektedir.

Esas olarak metaforik anlatım, iki durumdan veya iki yaşantıdan birini anlatmak için bilindik olan diğerine gönderme yapmak olarak tanımlanabilir. Aristo da bu durumu "bir olgunun, bir kavramın doğasını anlatmak veya hissettirmek için onu çok bilinen bir benzeriyle ilişkilendirerek veya kıyaslayarak anlatma" (Tunal1, 2002: 14) olarak tarif etmektedir.

Lakoff (1993)'a göre metaforik anlatım, "bir kavramı anlatırken ona benzer bir kavramı ifade etmek, geleneksel anlamının dışında bir kullanımla roman veya şiir diliyle ifade etmektir". Bu bağlamda "metaforik anlatım"1, benzetme, ilişkilendirme veya kıyaslama üzerine kurulmuş bir anlatım biçimi olarak görmek yanlış olmaz (Demir, 2017: 91-93). Ancak "ona benzer bir kavramın" varlığını ve benzerliğini toplumun önceden kabul etmesi ve iki kavram arasındaki benzerlik/ilişki/çağrışım olgusu, toplumda ortak algı hâline gelmiş olması beklenir. Yani metaforik bir anlatım için önce "metafor"un oluşması gerekir.

Aşağıdaki dörtlükteki "her türlü zorluğu göğüsleyerek yuvasını kurup yavrularını büyütmek ve neslini devam ettirmek isteyen bir kuş" metaforu kullanılmıştır. Dörtlüğü söyleyen sanatçı, neslini devam ettirmek için ağzıyla çer çöp toplayarak bir ağaca yuva yapan ve bu yuvasında yavrularını büyütmeye çalışan bu kuş ile kendi yaşantısı arasında benzerlik görmüştür. Bu benzerlikten yola çıkarak kendi üzüntü kaynağını daha vurgulu ve etkili bir anlatımla ifade etmek istemiş ve bunda da başarılı olmuştur. Çünkü iki hayat arasındaki benzerlik, toplumda önceden kabul görmüş ve doğru bir benzetme olarak umumiyet kazanmıştır. Sanatçı, anlatma gücünü bu ortak kabulden almaktadır. Burada (insan için) "kement atma", (kuş için) "çer çöp toplayıp yuva yaparak yavrularını büyütme" metaforları toplum hafızasında donmuş bir metafor hâline geldiği için şairin sözleri amacına ulaşmıştır: Sanatçı, "kuş" metaforunu bir benzetme unsuru olarak kullanmış ve onun yaşantısına gönderme yaparak metaforik bir anlatım kurmuştur.

"Kement attım dala ben

Düştüm haldan hala ben

Çöp devşirdim, yuva yaptım

Uçurmadım bala ben" 5

Hiçbir ifade tek başına metaforik değildir. Metafor, her ne kadar bir dilin sözlüğünde donmuş bir şekil olarak yer almasa da, bir kültür muhiti içinde ortak kabul hâline gelmiş bir kavram olarak toplumsal hafızada yerini almış ortak tasavvurlardır.

"Metaforlar, bir dilin asli varlığıdır. Çünkü dil sadece bir göstergeler imparatorluğu değil, aynı zamanda bir metaforlar imparatorluğudur..." (Lakoff ve Johnson, 2015: 9-10). Bunlar her ne kadar sözlüklere bir madde başı olarak konulmamış ise de pratikte yaşamakta ve bir anlaştırma

\footnotetext{
${ }^{5}$ Anonim
} 
aracı olarak görevini yapmaktadır. Bu tür anlatımlar; zamanla geleneksel vurgular, kalıplaşmış ifadeler, orta malı benzetmeler ve mecazlarla zengin ve etkili hâle gelebilir. Ancak edebî eserlerde, iddia ve ispata dayalı didaktikalarda, pedagojide kullanılan metaforların kendisi kadar kullanma biçimi ve kullanıldı̆̆ 1 yer de önemli olabilir.

Birçok kişi tarafından "özel bir anlatım biçimi” ya da "şiirsel bir dil” olarak algılanan metaforik anlatımlar, Lakoff ve Turner'a göre o kadar olağandır ve geleneksel hâle gelmiştir ki biz bu metaforları günlük konuşmanın içinde farkına varmadan kullanırız; bilerek veya bilmeden günlük hayatımızda metaforik anlatımlara sik sık başvururuz. Çoğu kez, metaforlarla yüklü ifadeleri anlam ayrıntılarını düşünmeden kullanmaya devam ederiz. Çünkü metaforlar, günlük hayatımızda düşüncelerimizin ve dilimizin ayrılmaz birer parçası hâline gelmiştir (Lakoff ve Turner, 1989).

Aşağıdaki dizelerde, ellerinde kement (yakalama ipi) olan çok sayıda insanın güzel bir av hayvanını (ahu) firdolayı çevirip yakalamaya çalıştıkları bir avlama olayı tasavvur edilmektedir. Sanatçı, bu tasavvurun toplumsal hafizada bir metafor olarak korunduğunu var saymış ve anlatımını bu metafor üzerine kurmuştur:

"Sevdalar kement olsa

Âşıklar levent olsa

Birbirine bent olsa

Ele geçmez o ahu" 6

Bu bağlamda, "metaforik" terimi, Türkçe Sözlük'te (TDK, 2011) açıklandığı gibi "metaforla ilgili olan" biçiminde değil, ancak "metafor yardımı ile anlatma" biçiminde açıklanabilir. Bu tarza kısaca "metaforik anlatım" diyoruz. Çünkü önümüzde bilindik bir olaya gönderme yaparak kurulmuş bir anlatım biçimi (telmih) vardır. Görüldüğü gibi metaforik anlatım, bir durumu başka bir durumla/olayla ilişkilendirme biçiminde de olabilir. Bu anlatım asla mecazla bir tutulamaz.

Özünde şifahi iletişimin biçimlendirdiği Türk kültüründe konuşma ve dinleme ile ilgili çok fazla metafor bulunmaktadır. Kültürümüzde "kulak" dinlemenin, "ağız/dil" konuşmanın sembolüdür ve ağız/dil-kulak ilişkisi üzerine Türkçede çok fazla metafor üretilmiştir. Örneğin birbirine çok yakın görünen "kulak misafiri olmak" ve "kulak kabartmak" deyimleriyle aslında birbirinden çok farklı durumlar anlatılmaktadır. Bu farklılı̆̆ anlatmak için bu deyimlerde birbirinden farklı metaforlar kullanılmıştır: "Kulak misafiri olmak" deyiminde "misafirlik" metaforu kullanılmıştır. Bir konuşmanın konusunu veya konuşanların neyi konuştuklarını merak edip kısaca yapılan iyi niyetli bir dinlemenin süresi ve niyeti, ziyaretini tamamlar tamamlamaz bulunduğu yerden ayrılmak isteyen misafirin durumu ve düşüncesiyle ilişkilendirilmiş̧ir. "Kulak kabartmak" deyiminde ise kulaklarını kaldırarak tüm dikkatiyle bir nokta üzerinde yoğunlaşan koca kulaklı bir "hayvan" metaforundan yararlanılmıştır. Bir yerde otlayan, su içen veya dinlenen bir hayvan, beklemediği bir ses işittiğinde kulaklarını anten gibi sesin geldiği tarafa çevirerek tüm dikkatini bu noktaya teksif eder. "Kulak kabartma" sözünün temel anlamı budur. Anlatılmak ve vurgulanmak istenen durum ise şöyledir: Kendi aralarında konuşan kişileri başka bir kişinin onlara belli etmeden gizlice dinlemeye çalışmasıdır. Esas olarak bu durum, toplumun hoş görmediği bir dinleme biçimidir. Dedikodu malzemesi toplamak, işittiklerini kendi çıkarları için kullanmak veya kendince mutlu olmak isteyen bir kişi, bu tutum ve davranışıyla, bir noktaya doğru kulaklarını çevirip sesleri dikkatle dinleyen bir hayvana benzetilmiştir. Toplumun hoş görmediği bir eylemi gerçekleştiren bu kişi; metaforik bir anlatımla koca kulaklı bir hayvana benzetilerek aşağılanmıştır.

\footnotetext{
${ }^{6}$ Vecdi Bingöl
} 
Yine dinlemekle ilgili "kulağı delik", "bir kulağından girip ötekinden çıkmak", "kulağına küpe olmak", "kulak tıkamak", "kulağına kar suyu kaçırmak", "kulak ardı etmek", "kulak asmamak" gibi deyimlerin de çeşitli metaforlarla oluşturulduğunu görmekteyiz.

Metaforik anlatımların Anadolu pedagojisinde de ilginç örneklerine rastlamaktayız: Anne kızına bir yemeğin yapılışını tarif ederken şöyle der: "Kızım, bu yemeğin tuzunu cimri atmalı, yağını zengin katmalı; bir deli de gelip bu yemeği karıştırmalı." $\mathrm{Bu}$ anlatımda, "cimri", "zengin" ve "deli" kelimeleriyle kodlanmış metaforlardan yararlanılmıştır. Asıl öğretilmek istenen şudur: Bu yemeği yaparken tencereye az miktarda tuz, bolca yağ konmalı ve yemek iyice (fazlaca) karıştırılmalıdır (Demir, 2017: 91). Bu öğretide "cimri" metaforu ile tuzun azlığı, "zengin" metaforu ile yağın bolluğu, "deli" metaforu ile de yemeğin çok karıştırılması gerektiği vurgulanmaktadır.

II. Meşrutiyet Dönemi eğitimcilerinden Emrullah Efendi'ye atfedilen "Tuba Ağacı Nazariyesi" adlandırılmasında da "tuba ağacı" metaforundan yararlanılmıştır. Tuba ağacı, kökleri yukarıda, dalları aşağıya doğru uzayan ve meyvelerini aşağı doğru sarkıtarak insanları besleyen bir cennet ağacı olarak tasavvur edilmiştir. Bu ağacın meyveleri yukarıdan gelir ve aşağıdaki ihtiyaç sahiplerine ulaşır. Emrullah Efendi'nin nazariyesi (eğitim teorisi) ise şöyledir: Bir toplumda maarifi geliştirmeye yukarıdan başlamak gerekir. Bunun için önce iyi öğretmenler yetiştirilmelidir. İyi yetişmiş öğretmen toplum için en uygun eğitimi bilir ve uygular. Bu nedenle eğitimde kalkınmaya yukarıdan başlanmalıdır. Eğitim tarihçileri, Emrullah Efendi'nin bu teorisine "tuba" metaforundan yararlanarak "Tuba Ağacı Nazariyesi" demişlerdir. Emrullah Efendi'nin eğitim-öğretimle ilgili görüşleri ile tuba ağacının özellikleri arasındaki benzerliğe dayanarak metaforik bir adlandırma yapılmıştır (Demir, 2017: 91).

Tüm metafik anlatımlar ve adlandırmalar, anlaşılması zor olan soyut bilgi veya kavramları görünür hâle getirme ve sözü tesirli kılma ihtiyacından doğmuştur. Metaforik anlatımların özünde, “... soyut ilişkileri anlamak veya formüle etmek amacıyla somut bir imgenin kullanılmasında yatmaktadır" (Draaisma, 2014). Soyut bilgilerin kavratılması, ancak somut bilgilerle ilişkilendirilerek kolaylaştırılabilir. Çünkü her metafor aslında bir somutlaştırmadır.

Metaforik anlatımlara kimi zaman da duygu, düşünce ve tasarımlarımızı güzel ve etkili bir ifade ile sunmak için başvururuz. Daha güzel anlatma, daha kalıcı izler bırakma, daha etkili olma ... düşüncesiyle başvurulan bu tür ifade biçimleri, yalnızca sanat eserlerinde değil, bilimsel çalışmalarda da çokça başvurulan bir bilgilendirme yöntemidir. Kolay anlaşılamayan müşahhas ve mücerret bilgi, olgu ve olayların anlatımında da metaforik yollara başvurulur.

Lowery (Lowery, 2013)'e göre bütün dillerde metafor vardır ve insanlar düşüncelerini ifade etmek için metaforlara başvururlar. Hatta bazı metaforlar evrenseldir. Çünkü bütün insanlar hayatlarında benzer şeyleri görür ve benzer duyguları yaşarlar.

\section{Metafor, Mecaz, Mazmûn}

İnsan zihnindeki kavramlar, kişisel ve toplumsal yaşamın genişletilmiş biçimi olan hayalleriyle sınırlıdır. Metaforik anlatımlar bu yaşantılardan ve hayallerden faydalanarak bilinmeyeni veya hayal edilemeyeni, bilinen ile anlatma biçimidir. Metaforik anlatımın temelinde ilişkilendirme veya çağrıştırma vardır. Sanatçı bu yolla kendi birikimlerini, düşünce veya hayal dünyasını muhatabının önbilgilerinden faydalanarak anlaşılır, görünür veya etkili kılmaya çalışır.

Metaforik anlatım, söz sanatının zirvesindeki geleneksel edebiyatımızda da (Divan Edebiyat1, Halk Edebiyat1, Türk Tasavvuf Edebiyatı) önemli bir yer tutmaktadır. Bilindiği gibi açık istiare, kapalı istiare, teşbih, telmih, kinaye, mecaz-1 mürsel, teşhis gibi söz sanatları tabiatı gereği gücünü bir metafordan alan söz sanatlarıdır. Geleneksel edebiyatımızda sanatçı, bu tür anlatımlarda kullandığı "referans" unsuruna "metafor" değil, "mazmûn" demekteydi. Bugünün münekkidi de Divan Şiirindeki bu tür metaforik anlatımlara "mecazî ifade", bu tarzın dayandığı asıl unsura da "mazmûn" demektedir. 
"Mazmûn" teriminin başka anlamları da olmakla birlikte yazınbilimde, "mânâ, kavram; nükteli, sa'natlı ince söz; kendisine özgü simgesel anlamları olan nükteli ve cinaslı söz" (Devellioğlu, 2010; Parlatır, 2017) şeklinde açıklanmaktadır. Görüldügü gibi "mazmûn" günümüzdeki metafor algısıyla tamamen örtüşmese de "metaforun donmuş/stabil hâli" olarak değerlendirilebilir. Klasik Türk Şiiri, bize dışarıdan mazmunlarla stilize edilmiş bir tabiatın veya kurmaca bir hayat tasviri gibi görünse de gerçek hayat bu mazmunların arkasında kalıyordu. Ancak bu mazmunları bilen ve anlayan şairi anlayabiliyordu. Zira klasik Türk şairi, hayatı bir "hayâlî" gibi mazmunları oynatarak tasvir etmekteydi. Okuyucusunu gerçekle buluşturan bu mazmunlar, Klasik Türk Edebiyatını baştan sona doldurmuştu. Öyle ki güzel bir mazmun tek başına şiiri kurtarmaya yetiyordu. Hatta herkesten önce tasavvur edilip söylenen bir mazmuna "bikr-i mazmûn" deniyordu. Her divan şairi, "mazmûn avcısı" gibi yeni bir mazmûn yakalamanın, bir kuyumcu titizliği ile de onu şiirde işlemenin gayreti içindeydi. "Gül ile bülbül" mazmûnu, "nergis" mazmûnu, "nokta" mazmûnu, "selvi/servi", "ab-1 revan" mazmûnu gibi. "Selvi" mazmûnu ile ince ve uzun boy, "nokta" mazmûnuyla yokluk ve vuslat, "karanlık" veya "gece" mazmûnuyla sevgilinin saçları, "kement" mazmûnuyla sevgilinin zülfü veya kakülü, "inci" mazmûnuyla sevgilinin diş̧leri, "kalem", "keman", "yay", "hilal" mazmûnuyla sevgilinin kaşları anlatılmak istenmiştir (Pala, 2014). Modern Türk edebiyatı, bu mazmunları bilen ve kullanmayı seven sanatçıların masasında emekleyerek gelişti. Bu mazmunların çoğu, geleneksel Türk edebiyatının ifade mirası olarak modern Türk edebiyatında da yaşamakta ve hâlen anlamaanlatma unsuru olarak kullanılmaktadır.

Toplumun muhayyilesinde gelişmekte olan veya stabil bir tasavvur hâlini almış olan metaforlar, leksik bir unsur gibi sözlüklerde madde başı yapılamaz. Çünkü metafor leksik bir malzeme değil, tabiatı gereği ansiklopedik bir malzemedir. Metafor; bir yaşantı, düşünüş, âdet, alışkanlık, meşhur bir olay, bir anekdot, bir aforizma hatta bir şahsiyetin etrafında ortaya çıkan gelişmeler de olabilir. Bunların tanımlanması mümkün değildir; anlaşılması ve amacına ulaşması için açıklanması gerekir. Daha da ötesi retorik kitaplarında, genel ansiklopedilerde veya güncel/tarihsel sözlüklerde bağlam içinde metinlerle gösterilmesi gerekir. Günlük konuşma dilinde, yazı dilinde ve edebiyatta bir anlatma/öğretme unsuru hâline gelmiş olan metaforların tespiti ve öğretilmesi için "Metafor Ansiklopedisi" hazırlanmalıdır. Bu materyal; hazırlanması, amacı ve içeriği bakımından asla terimler sözlüğü veya güncel sözlükler gibi düşünülmemelidir.

Batı literatüründe metaforlarla ilgili çok sayıda tarif ve tasnif çalışmaları yapılmış ve yapılmaktadır. Bu çalışmaların Türkçeye/Türk kültürüne uyarlanması ve özümsenmesi çok mümkün görünmemektedir. Zira bir kültür muhitinde oluşmuş metaforların millî özellikleri evrensel özelliklerinden daha ağır basmaktadır. Özellikle de metaforik anlatımlar millî üslup içinde biçimlenmekte ve gelenek hâlini almaktadır.

Metaforik anlatımların gayesi; bir düşünceyi, bir durumu, bir gerçeği veya hayali daha güzel anlatarak okuyucuya / dinleyiciye estetik bir hazzı yaşatmak da olabilir. Bu amaçla benzetme, ilişkilendirme veya çağrıştırma gayretiyle kurulan cümlelerde/mısralarda göndermeler-eşlemeler ne kadar kuvvetli, açık ve şaşırtıcı ise sanatçı o kadar başarılı olacaktır (Demir, 2017: 91-93).

"Beni kör kuyularda merdivensiz bıraktın"7 dizesinde şair içinde bulunduğu durumu ve duygularını "kör kuyu" sözünün okuyucu zihnindeki tasavvuruyla (kör kuyu metaforu) ilişkilendirmiştir. Buradaki "kuyu" gerçeğinin "kör" kelimesindeki olumsuz çağrışımlarla birleşerek muhatabın dünyasında oluşturduğu "çaresizlik" duygusu, "bilinmezlik" endişesi ve "yalnızlık" korkusu, şairin çıkış ya da hareket noktası olmuştur (Demir, 2017: 91-93).

"Can kafeste durmaz uçar

\footnotetext{
${ }^{7}$ Ümit Yaşar Oğuzcan
} 
Dünya bir han, konan göçer"8 misralarında şair, "kafes", "kafesten uçmak" ve "han" kelimeleri ile kodlanmış metaforları kullanarak insanoğlunun ölümlü olduğunu anlatmak istemiştir.

\section{“Kolun açmış yollarımı gözlüyor}

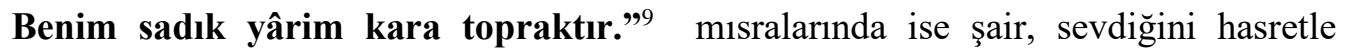
bekleyen bir insan metaforundan yararlanmıştır. Böyle bir âşıkla mezar (toprak) arasındaki benzerlikten yararlanarak metaforik bir anlatım kurmuştur.

"Güzel bir başlangıç yaptık ancak başarıya ulaşmak için önümüzdeki duvarı aşmamız gerekiyor." cümlesinde "duvar" metaforundan yararlanılmıştır.

"Biz bu sorunlarla mücadele ederken bazları hâlâ üç maymunu oynuyor." cümlesinde ise "üç maymun" sözünün halk hafızasındaki algısına (metafor) gönderme yapılmıştır.

Pedagoji, metaforik anlatımların bilinçli olarak kullanıldığı ilk alan olmalıdır. Çünkü metaforik anlatımların gerçek sebebi; eksiksiz ve doğru anlatma, öğretme, kabul ettirme ve sözü etkili kılma düşüncesidir. Bu nedenle pedagojinin kullandığı en eski yöntemin metaforik anlatım olduğunu söylemek yanlış olmaz. “... bireylerin soyut veya karmaşık olan olguları daha somut veya tecrübe edilen olgularla karşılaştırmalarını ve bu sayede de bilinmeyen olgulara ilişkin anlayış geliştirmelerini sağlarlar” (Saban vd., 2006: 463). Metaforlar, ayrıca öğrencilerin kendi öğrenmelerini yapılandırmalarını değerlendirmeleri açısından da önemli bir araçtır (Wegner ve Nückles, 2015: 96).

Metaforlar, bir kelime değil kelimelerin temel anlamı üzerine sonradan ilave edilmiş tasarımlardır. Bu sebeple üzerinde metafor olan kelimelerin eğitim-öğretimde terim olarak kullanılması son derece pedagojik bir yaklaşımdır. "Örs" kemiği, "üzengi" kemiği, "kürek" kemiği, "kaval" kemiği, göğüs "kafesi", omurilik "soğanı" insan anatomisiyle ilgili adlandırmalar metafoların pedagojide kullanıldığını gösteren örneklerdir.

\section{Sonuç}

"Metafor", "metaforik adlandırma" ve "metaforik anlatım" terimleriyle ifade edilen kavramlar, tasarım, varlık ve eylemler; tüm kültürlerde günlük yaşamın bir parçası hâline gelmiş olgulardır. Gerek günlük konuşmalarda gerekse anlatma, adlandırma ve eğitim-öğretim etkinliklerinde iletişim yaygın olarak bu metaforlar üzerinden sağlanmaktadır.

Metaforlar, toplumsal hafızada ortak kültür ürünü olarak varlığını sürdüren günlük hayat içerisinde herkes tarafından kullanılabilen ürünlerdir. Metafor kelime değildir, kelimeleri kullanma biçimi de değildir. Metafor kelimelerin bize çağrıştırdığı ve çoğu kez sözlükte açıklanmamış kavram ve tasavvurlardır. Metaforlar, günlük konuşmalarımızda anlama ve anlatmayı kolaylaştıran, sanat ürünlerinde söze estetik değer katan, eğitim-öğretimde ise kalıcı öğrenmelere zemin oluşturan çok çeşitli ve çok yönlü anlatım ögeleridir.

Metafor ve metaforik anlatımlar üzerindeki düşüncelerin Batı'daki tarihi, Aritoteles'e kadar uzanmaktadır. Aritoteles'in metafor üzerine söylemleri, yaptığı tarif ve tasnifler; bugün de araştırmacıların önünü aydınlatmaktadır. Türk literatüründe ise bu kavramlarla ilgili incelemelere geçtiğimiz yüzyılın son çeyreğinden itibaren rastlamaktayız. Hâlbuki metafor dediğimiz tasarım ve tasavvurların, Türk edebiyatında ve geleneksel Türk pedagojisinde yüzyıllardır anlatma ve öğretme unsuru olarak kullanıldığını biliyoruz. Zira metaforik anlatma ve adlandırma örneklerine Türk dilinin en eski yazılı metinlerinde bile rastlamaktayız. "Orhun Kitabelerinde 22 kavramsal metafor tespit edilmiştir." (Çetinkaya, 2018). Batı'da bu kavramın hem teorisi hem de pratiği ayrıntılı olarak incelenmiş, öğretimi tamamlanmıştır. Türkiye literatüründe ise "metafor" ve

${ }^{8}$ Âşık Veysel Şatıroğlu

${ }^{9}$ Âşık Veysel Şatıroğlu 
"metaforik" terimlerinin tespiti, açıklanması, tasnifi; söz estetiğinde ve pedagojide kullanımıyla ilgili çalışmalar henüz olgunlaşmış ve özümsenmiş değildir. Güncel sözlüklerde "metafor" kelimesi, "mecaz" ve mecazın çeşitleriyle açıklanmaktadır. "Metaforik anlatım" ve "metaforik adlandırma" terimleri ise henüz tartı̧̧maya açılmıştır. Türk Millî Eğitim Bakanlığı'nın yayımlamış olduğu eğitim terimleri sözlüğünde "metafor" teriminin madde başı olarak yer almamış olması Türk pedagojisinin bu terimle ilişkisini açıkça belgelemektedir.

Metaforlar, günlük konuşmalardan başka dilbilim, felsefe, semiyotik, anatomi, pedagoji, metin bilim gibi bilim dallarında anlatma ve öğretme unsuru olarak, retorikte ise söze estetik değer katan ve anlamayı kolaylaştıran anlatım malzemesi olarak kullanılmaktadır. Metafor olgusu, günlük hayatımıza öylesine girmiştir ki düşünme ve düşündürme aleti gibi her an aklımızda ve dilimizde hazır tutulan iletişim ögesi hâline gelmiştir.

Metafor/metaforlar, dil ve düşüncenin göz ardı edilemeyen gerçeğidir. Bu gerçeğin ögretilmesi ve bilinçli olarak kullanımının yaygınlaştırılması için en kısa zamanda müfredatının yapılması ve formel olarak eğitim-öğretimine başlanması gerekir.

\section{Kaynakça}

Akşehirli, S. (2005). Çağdaş Metafor Teorisi, http://www.egeedebiyat.org/modules.php? Name =Downloads\&d_op=getit\&lid=111 (Erişim tarihi: 24.08.2016).

Aristoteles, (2002). Poetika, (Hazırlayan: İsmail Tunalı) İstanbul: Remzi Kitabevi.

Arslan, M. M. ve Bayrakçı, M. (2006). "Metaforik Düşünme ve Öğrenme Yaklaşımının EğitimÖğretim Açısından İncelenmesi”. Millî Eğitim, S. 35(171).

Ayverdi, İ. (2016). Misalli Büyük Türkçe Sözlük, İstanbul: Kubbealtı Yayınları.

Balcı, A. (2003). "Eğitim Örgütlerine Yeni Bakış Açıları". Kuram ve Uygulamada Eğitim Yönetimi, 33, 26-61.

Çetinkaya, B. (2018). "Orhun Abidelerinde Metaforlar”, Uluslararası Bilim ve Eğitim Kongresi Tam Metin Bildiri Kitabl, 23-25 Mart 2018 Afyonkarahisar.

Danışman, S. A. (2015). "Metaforların Örgüt ve Yönetim Araştırmalarındaki Yeri: Ontolojik, Epistemolojik ve Metodolojik Kabuller Işı̆ğında Bir Değerlendirme”, Kafkas Üniversitesi İktisadi ve İdarî Bilimler Dergisi, 6(9), 47-64.

Demir, C. (2017). “Âşık Tarzı Türk Şiirinde Metaforlar”, Yeniceli Âşık Sıtkı Baba ve Popülerlik Çerçevesinde Kültür ve Sanat Sempozyumu Bildirileri.13-15 Ekim 2016.

Devellioğlu, F. (2010). Osmanlıca-Türkçe Ansiklopedik Lûgat, Ankara: Aydın Kitabevi Yayınları.

Doğan, D. M. (2014). Büyük Türkçe Sözlük, Ankara: Yazar Yayınları.

Draaisma, D. (2014). Bellek Metaforları Zihinle İlgili Fikirlerin Tarihi, (Tercüme: Gürol Koca), İstanbul: Metis Yayınları.

Dur, B. İ. U. (2016). Metafor ve Ekslibris, Uluslararası Ekslibris Dergisi, 3(5): 122-128.

Eraslan, L. (2011). Sosyolojik Metaforlar, Akademik Bakış Dergisi, (27): 1-22.

Filizok, R. (2001). Anlam Analizine Giriş, İzmir: Ege Üniversitesi Edebiyat Fakültesi Yayınları.

Hachette Éducation (2008). Dictionnaire Hachette Collége, Hachette Éducation Livre 2008, 43

Quai de Grenelle Paris cedex 15.

${ }^{10}$ Eğitim ve Eğitim Bilimleri Sözlüğü, Remzi Öncül, MEB Yayınları, Ankara 2000. 
Hoang, H. (2014). Metaphor and Second Language Learning: The State of the Field, The Electronic Journal for English as a Second Language, 18(2): 1-27.

Ivie, S.D. (2017). Metaphor, Paradigm and Education, Journal of Education, 52(1): 33-52.

Karaağaç, G. (2018). Dil Bilimi Terimleri Sözlüğü, Ankara: Türk Dil Kurumu Yayınları.

Karaçam, S. ve Aydın, F. (2014). Ortaokul Öğrencilerinin Teknoloji Kavramına İlişkin Algilarının Metafor Analizi, Gaziantep University Journal of Social Sciences, 13(2): 545-572.

Karataş, T. (2018). Ansiklopedik Edebiyat Terimleri Sözlüğü, İstanbul: İz Yayınc1lık.

Komisyon. (2011). Türkçe Sözlük, Ankara: Türk Dil Kurumu Yayınları.

Kudret, C. (2006). Örneklerle Edebiyat Bilgileri, İstanbul: İnkılâp Yayınevi.

Lakoff, G. ve Johnson, M. (2015). Metaforlar, (Çeviren: Gökhan Yavuz Demir), İstanbul: İthaki Yayınları.

Lakoff, G. (1993). The Contemporary Theory of Metaphor. A Ortany (Ed.) Metaphor and Thought. Second Edition, Cambridge: Cambridge Universtiy Press.

Lakoff, G. ve Johnson, M. (2015). Metaforlar, Hayat, Anlam ve Dil, (Çeviren: Gökhan Yavuz Demir), İstanbul: İthaki Yayınları.

Lakoff, G. ve Turner, M. (1989). More Than Cool Reason A Field Guide to Poetic Metaphor, Chicago: University of Chicago Press.

Lowery, D. (2013). Helping Metaphors Take Root in the EFL Classroom, English Teaching Forum, (1): 12-17.

Lyddon, W. J., Clay, A. L., Sparks, C. L. (2001), “Metaphor and Change in Counseling”, Journal of Counseling and Development, 79: 269-274.

Oğuz, Ö. (Ed.) (2004). Türk Halk Edebiyatı El Kitabı, Ankara: Grafiker Yayınları.

Oxford English Dictionary (1996). Oxford: Oxford University Press.

Ögel, B. (1991). Türk Kültür Tarihine Giriş, IV, Ankara: Kültür Bakanlığı Yayınları.

Pala, İ. (2014). Ansiklopedik Divân Şiiri Sözlüğü, İstanbul: Kapı Yayınları.

Parlatır, İ. (2017). Osmanlı Türkçesi Sözlü̆̈̈̈, Ankara: Yargı Yayınevi.

Saban, A. ve Koçbeker, B. N., Saban, A. (2006). “Öğretmen Adaylarının Öğretmen Kavramına İlişkin Algılarının Metafor Analizi Yoluyla İncelenmesi”, Kuram ve Uygulamada Eğitim Bilimleri, 6(2): 461-522.

Saraç, T. (1999). Büyük Fransızca-Türkçe Sözlük, İstanbul: Adam Yayınları.

Shuell, J. T. (1990). Teaching and Learning as Problem Solving, Theory into Practice, 29(2): $102-108$.

Türk Dil Kurkumu (2011), Türkçe Sözlük, Ankara: TDK Yayınları.

Wagener, A. E. (2017). Metaphor in Professional Counseling, The Professional Counselor, 7(2): $144-154$.

Wegner, E., Nückles, M. (2015). Training the Brain or Tending a Garden? Students' Metaphors of Learning Predict Self- Reported Learning Patterns, Frontline Learning Research, 3(4): 95109.

Zhang, F., Hu, J.(2009). A Study of Metaphor and its Application in Language Learning and Teaching”, International Educational Studies, 2(2): 77-81. 